\title{
PATTERNS OF FOOD SAFETY AND HYGIENE PRACTICES AMONG FOOD VENDORS IN GOVERNMENT PRIMARY SCHOOL, IKENNE LOCAL GOVERNMENT, OGUN STATE
}

\section{Leslie Tabitha A. ${ }^{1}$, Bitrus Hannah S. ${ }^{1}$, Abaribe Chidinma E. ${ }^{1}$, Okwuikpo Margaret I. ${ }^{2}$ and Maitanmi Julius O. ${ }^{1}$}

\author{
${ }^{1}$ Community/Public Health Nursing Department, Babcock University \\ ${ }^{2}$ Maternal and Child Health Department, Babcock University \\ *Corresponding Author Email: abaribech@babacock.edu.ng
}

\begin{abstract}
Cite this article:
Leslie T.A., Bitrus H.S., Abaribe C.E., Okwuikpo M.I., Maitanmi J.O. (2021), Patterns of Food Safety and Hygiene Practices Among Food Vendors in Government Primary School, Ikenne Local Government, Ogun State. African Journal of Health, Nursing and Midwifery 4(4), 1-13. DOI: 10.52589/AJHNMBH8QFWDV.
\end{abstract}

\section{Manuscript History \\ Received: 8 June 2021 \\ Accepted: 30 June 2021 \\ Published: 8 July 2021}

Copyright $($ ) 2020 The Author(s). This is an Open Access article distributed under the terms of Creative Commons AttributionNonCommercial-NoDerivatives 4.0 International (CC BY-NC-ND 4.0 ), which permits anyone to share, use, reproduce and redistribute in any medium, provided the original author and source are credited.
ABSTRACT: Food borne illness has continued to be a serious public health problem in developing countries especially among school children (who are known as the high-risk group for intestinal parasitic infections), and this can be prevented by good hygiene practices among vendors in the schools. School children are exposed to hazards of purchasing and consuming food from food vendors who may harbour dangerous pathogens or have the potential of spreading infection to a large number of other students, owing to their food safety and hygiene practices. Thus, the aim of this study was to determine the pattern of food safety and hygiene practices among food vendors in public primary schools in Ikenne Local Government Area, Ogun State, Nigeria. The study adopted a descriptive survey design and the target population comprised 48 food vendors. The analysis revealed that $8.3 \%$ of the respondents had low knowledge of food safety and hygiene, $18.8 \%$ had moderate knowledge and $72.9 \%$ of them had high knowledge of food safety and hygiene. One-third of the respondents (33.3\%) moderately practice food safety and hygiene and $66.7 \%$ highly practice food safety and hygiene. Factors that affected food safety and hygiene practices were access to protective equipment (100\%), access to potable water (100\%) and indoor food preparation environment (50\%). There was a significant difference in the pattern of practice of food safety and hygiene among food vendors based on the level of knowledge of food safety and hygiene practice $(p=0.000 ; t=45.208)$ and the level of education of the food vendors $(p=0.00 ; t=52.208)$. The study concluded that knowledge of food safety and hygiene practices among food vendors in public primary schools in Ikenne Local Government Area, Ogun State, Nigeria was high, though there was moderate practice. The study recommended that food vendors should be exposed to more training, regular monitoring, as well as providing basic facilities for food preparation in order to prevent the outbreak of food borne diseases among children.

KEYWORDS: Food Borne Diseases, Food Vendors, Knowledge, Practice, School Children. 


\section{INTRODUCTION}

Food is a basic human need that plays a vital role in the sustenance of life and the growth of school children. However, its safety and hygiene practices have become a major concern in school food programmes. This is because the consumption of contaminated food and water contributes to a myriad of health problems among school children, such as diarrhea, dysentery and worm infestation. Food vending in primary schools' form part of the integral diet of the school children. Food quality can affect the health, learning and physical activities of children of school-going age. Many of the food vendors underrate the school children and therefore do not strictly apply food hygiene practices to ensure that food served to these children are wholesome (Dubik, Henry, Ojo, Afoakwa, Amshawu \& Nwolley, 2018).

According to the Center for Disease Control and Prevention, (2017), the school environment is one of the several settings that can influence children's food choices and eating habits. Schools can ensure that the available food and beverages options are healthy, clean and help young people eat food that meet dietary recommendation of fruits, vegetables, whole grains and non-fat dairy products. Millions of children are affected by serious, yet easily treatable and preventable illness, which inhibit their ability to learn across the developing world. Particularly school children are at risk due to the neglect of basic food and personal hygiene practices.

Food safety and hygiene is the proper way and process of maintaining, processing and packaging food. In developing countries like Nigeria, traditional methods of processing and packaging food are evident in improper holding, inappropriate temperature, and poor personal hygiene of food handlers. These are commonly observed during food marketing and sales (Oghenekohwo, 2015). The principles of food safety and hygiene, according to World Health Organization (2015), are to prevent contaminating food with pathogens spreading from people, pets and pests, separate raw and cooked foods to prevent contaminating the cooked foods, cook foods for the appropriate length of time and at the appropriate temperature to kill pathogens, store at the proper temperature, and use safe water and safe raw materials while cooking food.

School feeding programmes can provide pupils the opportunity to practice healthy eating habits and consume safe food. In food insecure communities, these programs help to fight malnutrition and help keep children in school (Food and Agricultural Organization, 2018). Therefore, it is important that everyone-including food vendors-involved in food serving operations ensures food safety and hygiene (Asmawi, Norehan, Salikin, Rosdi, Munur, Basri, Selamat \& Nor, 2018). The food borne diseases are an important cause of morbidity and mortality worldwide with significant public health impact. Unsafe food creates a vicious cycle of diseases even among school children, diarrhea and malnutrition which significantly impedes public health and socioeconomic development (Iwu, Uwakwo, Duru, Diwe, Chineke, Merenu, Oluoha, Madubueze, Ndukwu \& Ohale, 2017).

When food is cooked in large scale, it may be handled by many individuals, thus increasing the chances of contamination of the final food due to improper handling. Deliberate or accidental contamination of food during large scale production might endanger the health of consumers, and have very expensive repercussions on a country (Akabanda, Hlortsi \& Kwarteng, 2017). Contaminated food can have severe consequences on the health of school children as children have poorly developed immunity compared with adults (Dubik, Henry, Ojo, Afoakwa, Amshawu \& Nwolley, 2018). Mishandling and disregard of proper hygiene by food vendors 
may enable the pathogenic bacteria to come into contact with food and, in some cases, survive and multiply in sufficient numbers to cause illness in consumers (Oghenekohwo, 2015).

Food infections follow the ingestion of bacteria, their toxins or viruses, which may result from eating of contaminated food or water from already contaminated food, or derived during processing from other foods by cross contamination (from surfaces, equipment and hands of catering staff); poisonous chemicals or other harmful substances can also cause food borne diseases. Most of the food borne diseases are preventable. Prevention involves limiting contamination all the way from the farm to the table. Therefore, careful steps should be taken from production of food, transportation, temporary storage, preparation, serving and consumption to avoid contamination of the food. Effective food hygiene control is vital to avoid the adverse effect on the health of school children. Good hygiene practices have been documented to prevent several foodborne diseases when practiced. It is broadly acclaimed that deliberate or accidental contamination of food due to inappropriate handling might endanger the lives of consumers. Food safety and hygiene patterns observed among food vendors include poor personal and environmental hygiene, inadequate storage, of food and drinks, and improper preparation and cooking (Faremi, Olatubi, \& Nnabuife, 2018).

Determining the pattern of food safety and hygiene practices among food vendors has become important due to an increase in reports of health problems associated with poor food hygiene. In Nigeria, regardless of the efforts of the government through its National Agency for Food and Drug Administration and Control (NAFDAC) to improve the safety of food supply, food safety still remains a major issue that has been exacerbated by the people's low knowledge of food safety and hygiene (WHO, 2015). Patterns of food safety and hygiene practices involve reliable sample of practices or observable characteristics that are necessary to ensure food contamination. According to World Health Organization (2015), there are five keys to safer food that are important in preventing foodborne illnesses. The five keys are: keep food surfaces clean; wash all utensils, plates, platters, and cutlery as soon as used; separate raw food from cooked food; cook food thoroughly to the appropriate temperature; keep food at safe temperature, both for serving and storage; and use safe water and raw materials.

Adequate hygiene is expected to be ensured during shopping, storage, thawing, preparation, cooking, serving, and leftovers (USDA, 2015). Constant food borne infections pose a serious threat to good health and affect the growth and development of school children, and this can only be curbed if good food safety practices are adhered to by the school vendors to prevent and control food borne diseases. The researchers observed a poor practice of food safety among food vendors in Ilishan-Remo during a school health programme and therefore the need for this study to determine the patterns of food safety and hygiene practices among food vendors in public primary schools, Ilishan Remo, Ogun State.

\section{Research Questions}

1. What is the level of knowledge on food safety and hygiene practices of food vendors in public primary schools in Ikenne Local Government Area?

2. What are the food safety and hygiene practices among food vendors in public primary schools in Ikenne Local Government Area?

3. What are the factors that influence food safety and hygiene practices among food vendors in public primary schools in Ikenne Local Government Area? 
4. What is the proportion of food vendors that have had training on food safety and hygiene practices in public primary schools in Ikenne Local Government Area?

\section{Hypotheses}

1. There is no significant difference in the pattern of practice of food safety and hygiene among food vendors based on level of knowledge of food safety and hygiene practice.

2. There is no significant difference in the practice of food safety and hygiene practice among food vendors based on the level of education of food vendors.

\section{Methodology}

The research adopted a cross-sectional descriptive survey design which involved investigation and description of the patterns of food safety and hygiene practices among food vendors. The target population of the study comprised 48 food vendors working in government primary schools in Ikenne Local Government Area, Ogun State. The instrument for data collection had 2 sections: Section A ascertained the demographic data of the respondents and section B contained information based on knowledge and practice of food safety. Face and content validity of the instrument was ensured. The reliability was ascertained using Cronbach's alpha; the overall reliability index for the instrument was 0.814 . The collected data was analyzed using both descriptive and inferential statistics. Descriptive statistics-frequency, percentage, mean and standard deviation - were used to summarize the demographic data and objectives of the study. Inferential statistics - chi-square Test of association-was used to test the hypotheses at 0.05 level of significance. Hence, statistical relationship/association exists when p-value is less than $0.05(<0.05)$. Analysis of data was done with the SPSS version 20.0.

\section{Ethical Consideration}

Ethical approval was obtained from Babcock University Health Research Ethical Committee (BUHREC). A letter was also collected from the School of Nursing, Babcock University, to the head of the Government-owned primary schools in Ikenne Local Government Area to grant permission for the questionnaire to be administered among the food vendors. Consent was obtained from the respondents before administering the questionnaire. The purpose and content of the questionnaire was explained to the respondents; this was done in order to gain maximum cooperation in obtaining correct and unbiased information. Privacy and respect for human dignity was observed during and after data collection among respondents. The respondents were assured of confidentiality of any information before, during and after collection of data.

\section{RESULTS}

Table 1: Socio-Demographic Characteristics of the Respondents $(n=48)$

\begin{tabular}{|c|c|c|c|}
\hline \multicolumn{2}{|l|}{ Item } & Frequency (n) & Percentage (\%) \\
\hline \multirow[t]{5}{*}{ Age } & $23-27$ years & 5 & 10.4 \\
\hline & $28-32$ years & 6 & 12.5 \\
\hline & $33-37$ years & 10 & 20.8 \\
\hline & 38 years and above & 27 & 56.3 \\
\hline & Total & 48 & 100.0 \\
\hline
\end{tabular}




\begin{tabular}{|c|c|c|c|}
\hline \multirow[t]{3}{*}{ Gender } & Male & 0 & 0.0 \\
\hline & Female & 48 & 100.0 \\
\hline & Total & 48 & 100.0 \\
\hline \multirow[t]{5}{*}{ Marital Status } & Single & 7 & 14.6 \\
\hline & Married & 24 & 50.0 \\
\hline & Separated/Divorced & 9 & 18.7 \\
\hline & Widow & 8 & 16.7 \\
\hline & Total & 48 & 100.0 \\
\hline \multirow{5}{*}{$\begin{array}{l}\text { Highest Educational } \\
\text { Level }\end{array}$} & No Formal Education & 8 & 16.7 \\
\hline & Primary Education & 24 & 50.0 \\
\hline & Secondary Education & 12 & 25.0 \\
\hline & Tertiary Education & 4 & 8.3 \\
\hline & Total & 48 & 100.0 \\
\hline \multirow{3}{*}{$\begin{array}{l}\text { Length of time as a } \\
\text { vendor }\end{array}$} & $<5$ years & 29 & 60.4 \\
\hline & $<5$ years & 19 & 39.6 \\
\hline & Total & 48 & 100.0 \\
\hline \multirow[t]{3}{*}{ Received Training } & Yes & 41 & 85.4 \\
\hline & No & 7 & 14.6 \\
\hline & Total & 48 & 100.0 \\
\hline
\end{tabular}

Table 1 above showed that $5(10.4 \%)$ of the respondents fall within the age bracket of 23-27 years, $6(12.5 \%)$ between 28-32 years, $10(20.8 \%)$ between 33-37 years while the majority, $27(56.3 \%)$ of the respondents are 38 years and above. All respondents are females. The profile of the relationship indicted those $7(14.6 \%)$ respondents are single, 24 (50.0\%) married, 9 $(18.8 \%)$ are either separated or divorced and $8(16.7 \%)$ divorced. When the educational profile of the respondents were analysed, $8(16.7 \%)$ had no formal education, $24(50.0 \%)$ had primary education and $12(25.0 \%)$ had secondary education. The number of respondents who had tertiary education was $4(8.3 \%)$. On the length of time as a food vendor, $29(60.4 \%)$ indicated that they have not been food vendors for up to five years while nineteen (19) of the respondents indicated that they have been food vendors for more than 5 years. The proportion of respondents that have received training were $41(85.4 \%)$. The number of respondents that have not received training were $7(14.6 \%)$. The demographic characteristics show that all the respondents are qualified to respond to this survey. With the diverse sample of experienced respondents, we can confidently infer that the respondents' responses will provide adequate data that will provide answers to the question raised and achieve the objective of the study.

Table 2: Respondents' Responses on Knowledge of Food Safety and Hygiene Practices

\begin{tabular}{|c|c|c|c|c|c|c|}
\hline \multicolumn{2}{|l|}{ Variable } & $\begin{array}{l}\text { Frequency } \\
\text { (n) }\end{array}$ & $\begin{array}{l}\text { Percentage } \\
(\%)\end{array}$ & Mean & STD & Remark \\
\hline \multirow{3}{*}{$\begin{array}{l}\text { When is the } \\
\text { best time to } \\
\text { clean cooking } \\
\text { utensils? }\end{array}$} & $\begin{array}{l}\text { Before and } \\
\text { after } \\
\text { cooking }\end{array}$ & 35 & 72.9 & \multirow[t]{3}{*}{1.73} & \multirow[t]{3}{*}{0.449} & \multirow{3}{*}{$\begin{array}{l}\text { Knowledge mean } \\
\text { Score }=5.104, \\
\text { Standard deviation } \\
=0.881 \\
\text { Low Knowledge } \\
=4(8.3 \%)\end{array}$} \\
\hline & $\begin{array}{l}\text { Only when } \\
\text { it is dirty }\end{array}$ & 13 & 27.1 & & & \\
\hline & Total & 48 & 100.0 & & & \\
\hline
\end{tabular}




\begin{tabular}{|c|c|c|c|c|c|c|}
\hline \multirow{3}{*}{$\begin{array}{l}\text { Reheating cold } \\
\text { food before } \\
\text { consumption is } \\
\text { good }\end{array}$} & Not Good & 15 & 31.2 & \multirow[t]{3}{*}{1.69} & \multirow[t]{3}{*}{0.468} & \multirow{3}{*}{$\begin{array}{l}\text { Moderate } \\
\text { Knowledge } \\
=9(18.8 \%)\end{array}$} \\
\hline & Good & 33 & 68.8 & & & \\
\hline & Total & 48 & 100.0 & & & \\
\hline \multirow{3}{*}{$\begin{array}{l}\text { When should } \\
\text { Vegetables be } \\
\text { washed? }\end{array}$} & $\begin{array}{l}\text { Before } \\
\text { cutting it }\end{array}$ & 33 & 68.8 & \multirow[t]{3}{*}{1.69} & \multirow[t]{3}{*}{0.468} & \multirow{3}{*}{$\begin{array}{l}\text { High Knowledge } \\
=35(72.9 \%)\end{array}$} \\
\hline & $\begin{array}{l}\text { After } \\
\text { cutting it }\end{array}$ & 15 & 31.2 & & & \\
\hline & Total & 48 & 100.0 & & & \\
\hline
\end{tabular}

Table 2 above showed the knowledge of respondents on food safety and hygiene practices. The result on knowledge of food safety and hygiene practices revealed that the mean knowledge score of respondents who clean their utensils before and after cooking was 1.73. When asked when is the best time to clean cooking utensils, 35 (72.9\%) of the respondents indicated before and after cooking and $13(27.1 \%)$ indicated only when it is dirty. When the respondents were asked on reheating cold food before consumption, it was found that $33(68.8 \%)$ indicated that it is good to reheat cold food before consumption while $15(31.3 \%)$ indicated that it is not good. Thirty-three $(68.8 \%)$ of the respondents indicated that vegetables should be washed before cutting and $15(31.2 \%)$ indicated that vegetables should be washed after cutting. From the analysis, in summary, 4 respondents, representing $8.3 \%$, had low knowledge of food safety and hygiene while $9(18.8 \%)$ of the respondents had moderate knowledge of food safety and hygiene. Majority, 35 (72.9\%) of the respondents had high knowledge of food safety and hygiene. The aggregate mean score for knowledge of food safety and hygiene was 5.104 with a standard deviation of 0.881 , indicating that the responses on knowledge were not far apart.

Table 3a: Respondents' Responses on Practices of Food Safety and Hygiene

\begin{tabular}{|c|c|c|c|c|c|c|c|c|}
\hline Variable & $\begin{array}{c}\text { Rarely } \\
\text { n } \\
(\%)\end{array}$ & $\begin{array}{c}\text { Sometimes } \\
\text { n } \\
(\%)\end{array}$ & $\begin{array}{c}\text { Often } \\
\text { n } \\
(\%)\end{array}$ & $\begin{array}{c}\text { Always } \\
\text { n } \\
(\%)\end{array}$ & $\begin{array}{c}\text { Total } \\
\text { n } \\
(\%)\end{array}$ & Mean & St.D & Remark \\
\hline $\begin{array}{l}\text { How often do you } \\
\text { clean cooking } \\
\text { environment? }\end{array}$ & $\begin{array}{l}1 \\
(2.1)\end{array}$ & $\begin{array}{l}1 \\
(2.1)\end{array}$ & $\begin{array}{l}20 \\
(41.7)\end{array}$ & $\begin{array}{l}26 \\
(54.2)\end{array}$ & $\begin{array}{l}48 \\
100.0\end{array}$ & 3.48 & 0.652 & \multirow{3}{*}{$\begin{array}{l}\text { Practice Mean } \\
\text { Score }= \\
19.833 \\
\text { Standard } \\
\text { Deviation = } \\
2.157 \\
\text { Low Practice } \\
=0(0.0 \%)\end{array}$} \\
\hline $\begin{array}{l}\text { How often do you } \\
\text { wash your hands } \\
\text { with soap and water } \\
\text { before cooking? }\end{array}$ & $\begin{array}{l}3 \\
(6.3)\end{array}$ & $\begin{array}{l}9 \\
(18.8)\end{array}$ & $\begin{array}{l}10 \\
(20.8)\end{array}$ & $\begin{array}{l}26 \\
(54.2)\end{array}$ & $\begin{array}{l}48 \\
100.0\end{array}$ & 3.23 & 0.973 & \\
\hline $\begin{array}{l}\text { How often do you } \\
\text { cook food } \\
\text { thoroughly before } \\
\text { consumption? }\end{array}$ & $\begin{array}{l}9 \\
(18.8)\end{array}$ & $\begin{array}{l}0 \\
(0.0)\end{array}$ & $\begin{array}{l}4 \\
(8.3)\end{array}$ & $\begin{array}{l}35 \\
(72.9)\end{array}$ & $\begin{array}{l}48 \\
100.0\end{array}$ & 3.35 & 1.176 & \\
\hline $\begin{array}{l}\text { How often do you } \\
\text { rinse the plate } \\
\text { before serving } \\
\text { food? }\end{array}$ & $\begin{array}{l}1 \\
(2.1)\end{array}$ & $\begin{array}{l}5 \\
(10.4)\end{array}$ & $\begin{array}{l}8 \\
(16.7)\end{array}$ & $\begin{array}{l}34 \\
(70.8)\end{array}$ & $\begin{array}{l}48 \\
100.0\end{array}$ & 3.56 & 0.769 & $\begin{array}{l}\text { Moderate } \\
\text { Practice } \\
=16(33.3 \%)\end{array}$ \\
\hline $\begin{array}{l}\text { How often do you } \\
\text { wash cutting board } \\
\text { before using it for } \\
\text { food? }\end{array}$ & $\begin{array}{l}1 \\
(2.1)\end{array}$ & $\begin{array}{l}3 \\
(6.3)\end{array}$ & $\begin{array}{l}5 \\
(10.4)\end{array}$ & $\begin{array}{l}39 \\
(81.3)\end{array}$ & $\begin{array}{l}48 \\
100.0\end{array}$ & 3.71 & 0.683 & $\begin{array}{l}\text { High Practice } \\
=32(66.7 \%)\end{array}$ \\
\hline
\end{tabular}


Table 3b: Respondents' Responses on Practices of Food Safety and Hygiene

\begin{tabular}{|l|l|l|l|l|l|}
\hline Variable & $\begin{array}{l}\text { Yes } \\
\mathbf{n} \\
(\boldsymbol{\%})\end{array}$ & $\begin{array}{l}\text { No } \\
\mathbf{n} \\
(\boldsymbol{\%})\end{array}$ & Total & Mean & StD \\
\hline $\begin{array}{l}\text { Do you wash your hands after using } \\
\text { the toilet? }\end{array}$ & $\begin{array}{l}36 \\
(75.0)\end{array}$ & $\begin{array}{l}12 \\
(25.0)\end{array}$ & $\begin{array}{l}48 \\
100.0\end{array}$ & 1.25 & 0.438 \\
\hline $\begin{array}{l}\text { Do you separate raw and cooked } \\
\text { foods? }\end{array}$ & $\begin{array}{l}36 \\
(75.0)\end{array}$ & $\begin{array}{l}12 \\
(25.0)\end{array}$ & $\begin{array}{l}48 \\
100.0\end{array}$ & 1.25 & 0.438 \\
\hline
\end{tabular}

Table $3 \mathrm{a}$ and Table $3 \mathrm{~b}$ showed the response of the respondents on practice of food safety and hygiene practices. From Table 3a, it can be observed that when the respondents were asked how often they clean their cooking environment, 1 (2.1\%) indicated rarely, $1(2.1 \%)$ sometimes, $20(41.7 \%)$ often and $26(54.2 \%)$ always. In summary, the respondents indicated that they often clean their cooking environment $($ Mean $=3.48, \mathrm{STD}=0.652)$. Furthermore, when asked how often they wash their hands with soap and water before cooking, $3(6.3 \%)$ of the respondents indicated rarely, 9 (18.8\%) sometimes, 10 (20.8\%) often and $26(54.2 \%)$ always wash their hands with soap and water before cooking. On the average, the respondents indicated that they always clean their cooking environment $(\mathrm{Mean}=3.23, \mathrm{STD}=0.973)$. More so, on the question of how often they cook food thoroughly before consumption, $9(18.8 \%)$ of the respondents indicated rarely, $4(8.3 \%)$ often and $35(72.9 \%)$ indicated that they always cook food thoroughly before consumption. On the average, the respondents indicated that they often cook food thoroughly before consumption (Mean $=3.35, \mathrm{STD}=1.176)$. Furthermore, $1(2.1 \%)$ of the respondents rarely rinse the plate before serving food, $5(10.4 \%)$ sometimes, $8(16.7 \%)$ often and 34(70.8\%) indicated that they always rinse the plate before serving food. On the average the respondents always rinse the plate before serving food (Mean $=3.56, \mathrm{STD}=0.769$ ). Furthermore, when asked how often they wash cutting board before using it for food, $1(2.1 \%)$ of the respondents indicated rarely, $3(6.2 \%)$ sometimes, $5(10.4 \%)$ often and $39(81.3 \%)$ always wash cutting board before using it for food (Mean $=3.71$, STD $=0.683$ ). From table $4.3 \mathrm{~b}, 36(75.0 \%)$ indicated in the affirmative (yes) that they wash their hands after using the toilet, $12(25.0 \%)$ indicated no. Respondents who indicated that they separate raw and cooked foods were $36(75.0 \%)$ and those who indicated no were $12(25.0 \%)$. In summary, from the analysis on food safety and hygiene practices, $16(33.3 \%)$ respondents moderately practice food safety and hygiene, and $32(66.7 \%)$ of the respondents highly practice food safety and hygiene. The overall practice level of food and safety hygiene of the food vendors was 19.83. The standard deviation was 2.16 , indicating that their responses on practice differ widely. 
Table 4: Respondents' Responses on Factors Affecting Food Safety and Hygiene Practices

\begin{tabular}{|c|c|c|c|c|c|}
\hline \multicolumn{2}{|l|}{ Variable } & $\begin{array}{l}\text { Frequency } \\
\text { (n) }\end{array}$ & $\begin{array}{l}\text { Percentage } \\
(\%)\end{array}$ & Mean & STD \\
\hline \multirow{3}{*}{$\begin{array}{l}\text { Where do you prepare } \\
\text { food? }\end{array}$} & Indoor & 24 & 50.0 & \multirow{3}{*}{1.50} & \multirow[t]{3}{*}{0.505} \\
\hline & Outdoor & 24 & 50.0 & & \\
\hline & Total & 48 & 100.0 & & \\
\hline \multirow{5}{*}{$\begin{array}{l}\text { How do you dispose food } \\
\text { waste? }\end{array}$} & Bush & 11 & 22.9 & \multirow[t]{5}{*}{2.83} & \multirow[t]{5}{*}{1.209} \\
\hline & Road Side & 6 & 12.5 & & \\
\hline & Burning & 11 & 22.9 & & \\
\hline & Refuse Dump & 20 & 41.7 & & \\
\hline & Total & 48 & 100.0 & & \\
\hline \multirow{5}{*}{$\begin{array}{l}\text { How do you preserve } \\
\text { food? }\end{array}$} & Sun drying & 12 & 25.0 & \multirow[t]{5}{*}{2.73} & \multirow[t]{5}{*}{1.267} \\
\hline & Smoking & 10 & 20.8 & & \\
\hline & Refrigeration & 5 & 10.4 & & \\
\hline & Not Applicable & 21 & 43.8 & & \\
\hline & Total & 48 & 100.0 & & \\
\hline \multirow{5}{*}{$\begin{array}{l}\text { How often do you have } \\
\text { access to protective } \\
\text { equipment while serving } \\
\text { food? }\end{array}$} & Rarely & 3 & 6.3 & \multirow[t]{5}{*}{3.38} & \multirow[t]{5}{*}{0.815} \\
\hline & Sometimes & 1 & 2.1 & & \\
\hline & Often & 19 & 39.6 & & \\
\hline & Always & 25 & 52.1 & & \\
\hline & Total & 48 & 100.0 & & \\
\hline \multirow{5}{*}{$\begin{array}{l}\text { How often do you have } \\
\text { adequate cleaning water } \\
\text { for washing? }\end{array}$} & Rarely & 0. & 0.0 & \multirow[t]{5}{*}{3.71} & \multirow[t]{5}{*}{0.504} \\
\hline & Sometimes & 1 & 2.1 & & \\
\hline & Often & 12 & 25.0 & & \\
\hline & Always & 35 & 72.9 & & \\
\hline & Total & 48 & 100.0 & & \\
\hline
\end{tabular}

Table 4 showed the respondents' responses on factors that affect their practice of food safety and hygiene practices. When the respondents were asked where they prepare food, equal number, $24(50.0 \%)$ indicated indoor and outdoor. It was observed that $11(22.9 \%)$ mentioned that bush was where they dispose their waste, $6(12.5 \%)$ indicated road side, $11(22.9 \%)$ burning and $20(41.7 \%)$ refuse dump. Twelve $(25.0 \%)$ use sun drying to preserve food, 10 (20.8\%) make use of smoking, $5(10.4 \%)$ refrigeration and $21(43.8 \%)$ did not indicate any way of preserving food. When the respondents were asked on how often they have access to protective equipment while serving food, it was found that $3(6.3 \%)$ indicated rarely, $1(2.1 \%)$ sometimes, 19 (39.6\%) indicated often and 25 (52.1\%) indicated always. Furthermore, $2.1 \%$ of the respondents sometimes have adequate water. Twelve $(25 \%)$ of the respondents often have adequate water for washing. The proportion of respondents that indicated that they always have adequate water for washing were $35(72.9 \%)$. The mean ranges from 1.50 to 3.71 and standard deviation from 0.504 to 1.267 . 


\section{Hypotheses}

\section{Hypothesis One}

Ho1: There is no significant difference in the pattern of practice of food safety and hygiene among food vendors based on level of knowledge of food safety and hygiene practice.

Table 5: Test of Difference between Practice of Food Safety and Hygiene Based on the Knowledge of Food Safety and Hygiene

\begin{tabular}{|c|c|c|c|c|c|}
\hline $\begin{array}{l}\text { Knowledge/ } \\
\text { Practice }\end{array}$ & Low & Moderate & High & Total & Result \\
\hline $\begin{array}{l}\text { Knowledge of food } \\
\text { safety and hygiene } \\
\text { practice }\end{array}$ & 4 & 9 & 35 & 48 & \multirow[t]{2}{*}{$\begin{array}{l}p=0.000 \\
t=45.208 \\
\text { Error }=0.325\end{array}$} \\
\hline $\begin{array}{l}\text { Food safety and } \\
\text { hygiene practice }\end{array}$ & 0 & 16 & 32 & 48 & \\
\hline
\end{tabular}

The hypothesis was to test whether a difference exists in the practice of food safety and hygiene based on the knowledge of safety and hygiene. The test result showed a t-test statistics of $\mathrm{t}=$ 45.208 and $p=0.000$, showing a statistical significance. We therefore reject the null hypothesis that says there is no significant difference in the pattern of practice of food safety and hygiene among food vendors based on the level of knowledge of food safety and hygiene practice. This means that the knowledge of food safety and hygiene played a role in the practice of food safety among the food vendors in Ikenne LGA.

\section{Hypothesis Two}

Ho2: There is no significant difference in the practice of food safety and hygiene practice among food vendors based on the level of education of food vendors.

Table 6: Test of Difference between Practice of Food Safety and Hygiene Based on the Level of Education of Food vendors

\begin{tabular}{|c|c|c|c|c|c|}
\hline \multirow[t]{2}{*}{ Educational Level } & \multicolumn{4}{|c|}{ Practice } & \multirow{7}{*}{$\begin{array}{l}\text { Test Result } \\
p=0.000 \\
t=52.208 \\
\text { Error }=0.326\end{array}$} \\
\hline & Low & Moderate & High & Total & \\
\hline No formal Education & 0 & 6 & 2 & 8 & \\
\hline Primary Education & 0 & 7 & 17 & 24 & \\
\hline Secondary Education & 0 & 2 & 10 & 12 & \\
\hline Tertiary Education & 0 & 1 & 3 & 4 & \\
\hline Total & 0 & 16 & 32 & & \\
\hline
\end{tabular}

The above hypothesis was to test whether a significant difference exists in the practice of food safety and hygiene based on the level of educational attainment of the food vendors. The test result showed a t-test statistics of $\mathrm{t}=52.559$ and $p=0.000$, showing a statistical significance. Therefore, we reject the null hypothesis that says there is no significant difference in the pattern of practice of food safety and hygiene among food vendors based on the level of educational 
of food vendors. This means that educational level played a role in the practice of food safety among the food vendors in Ikenne LGA.

\section{DISCUSSION OF FINDINGS}

Respondents above 38 years old constituted the majority, 27 (56.3\%) of the sample. Majority of the respondents have primary education. Twenty-four $(50.0 \%)$ had primary education. The number of respondents who had tertiary education was $4(8.3 \%)$. On the length of time as a food vendor, $29(60.4 \%)$ indicated that they have not been food vendors for up to five years. The proportion of respondents that have received training were in majority, 41 (85.4\%).

Assessment of the the level of knowledge on food safety and hygiene practices of food vendors in public primary schools in Ikenne Local Government Area revealed that the majority of the respondents had high knowledge of food safety and hygiene practices. Also, the responses on knowledge by the respondents was not far apart, indicating that majority share similar view on knowledge of food safety and hygiene. The findings of this study correlates with the findings of Afolaranmi, Hassan, Bello and Misari (2015), who carried out a study on the knowledge and practice of food safety and hygiene among 174 food vendors in primary schools in Jos, Plateau State, North central Nigeria. The authors found that the respondents had good knowledge of hygiene. Reasons for this similarity can be attributed to training provided. The general understanding was that structured food safety and hygiene training improve knowledge of delivery of wholesome food to the consumers.

The finding from this study revealed that respondents had moderate level of practice of food safety and hygiene. The findings corroborate the findings of Faremi, Olatubi and Nnabuife (2018), who carried out a research on food safety and hygiene practices among 238 food vendors in a tertiary educational institution in southwestern Nigeria. Their study revealed that majority (79.8\%) of the respondents checked for expiry dates of all products; on the other hand, about half of them have never used a thermometer to check the temperature of food. Majority of the correspondents agree that foods can be contaminated with microbes by coming in contact with unsafe foods; $61.8 \%$ agree that soap and water can kill all harmful microbes. Although, the question content of this study differs from theirs, the underlining point suggested that the rate at which respondents respond to the practice of food safety and hygiene seems related. In this study, when the question of how often respondents cook food thoroughly was asked, only $35(72.9 \%)$ indicated they always cook food thoroughly before consumption. Respondents who indicated that they separate raw foods from cooked foods were $36(75.0 \%)$ and those who indicated no were $12(25.0 \%)$.

In assessing the factors that influence food safety and hygiene practices among food vendors in public primary schools in Ikenne Local Government Area, the following factors were identified to influence food safety and hygiene practices: adequate water for washing, assess to protective equipment while serving food, refrigeration system to preserve food, inadequate waste disposal system and conducive environment for food preparation. The findings correlate with the findings of Zenebe, Gebremedhin, Henry and Regassa (2018), who conducted a study on the effect of school feeding program on dietary diversity, nutritional status and class attendance of school children in Boricha district, Southern Ethiopia. 
This study also revealed that majority of the food vendors were trained on food safety and hygiene practices. This seem to portray a different opinion from the study conducted by Emmanuel, Mangai, Kayong, Afoi, Goshit, Nanman and Innocent (2015), who assessed the practice of food safety and hygiene among 200 food vendors in Jos North Local Government Area of Plateau State. Their study revealed that $81.5 \%$ of food vendors never received any training on food handling while only $18.5 \%$ claim to have received it. The difference in the study findings could be traced to possible reasons for difference in the time of introduction of the school feeding programme in Nigeria.

Furthermore, hypotheses were tested and they revealed that there was a significant difference in practice of food safety and hygiene on account of the knowledge of food safety by vendors. This implies that knowledge of food safety and hygiene played a role in the practice of food safety among the food vendors in Ikenne LGA. The result of the second hypothesis, which was tested to determine whether a significant difference existed in the practice of food safety and hygiene based on the level of educational attainment of food vendors, showed a significant difference, meaning that the level of education of food vendors played a role in the practice of food safety among food vendors in Ikenne LGA. The findings are related to the findings of the study by Ezenwoko, Awosan, Oche, Makusidi, Abubakar and Raji (2017), carried out among 263 food handlers in Sokoto, Nigeria, who reported significant association between good knowledge of food hygiene among respondents with formal education and practice.

\section{Implication for Nursing Practice}

The study will provide a baseline data for the healthcare system and a feedback to healthcare providers on what is to be expected as regards food hygiene and safety practices among food vendors. This study has created awareness of food and safety practices and factors that influence them; this will enable nurses to design and implement simple easy to use guidelines on how to educate and reform the food vendors on food handling. It also provides a point of discussion where patients attend hospitals based on preventable diseases from contaminated foods.

\section{CONCLUSION}

The study was conducted among 48 food vendors to assess food safety and hygiene practices in primary schools in Ikenne LGA. Majority of the respondents were above 38 years and had good knowledge of food safety and hygiene practices but had a fair practice of food safety and hygiene practices.

\section{RECOMMENDATIONS}

1. Food vendors should be encouraged to form a forum or group where they can share knowledge, experience and invite resource persons, such as community/public health nurses, to talk on food safety and hygiene practices. 
2. Government and regulatory agencies need to provide basic amenities so that food vendors will readily abide by the food safety and hygienic standards, in order to prevent the occurrence of foodborne illnesses and meet the expectation of consumers and stakeholders.

3. The school authority should set up committees that will perform routine checks on the food vendors.

4. Preservation is a challenge for the food vendors; thus, it is recommended that training on thawing should be given to vendors and a cqentral refrigeration system can be provided to vendors in places where they cannot afford to buy and maintain a refrigerator.

5. Water is essential in food preparation and should be provided by the government and the school authorities.

\section{REFERENCES}

Afolaranmi, T.O., Hassan, Z., Bello, D.A., Tagurum, Y.O., Miner, C.A., Zoakah. A., Ogbonna, C. (2014). Training: A vital tool for improving the knowledge and practice of food safety and hygiene among food handlers in boarding secondary schools in Plateau State. Journal of medicine in the tropics, 16(2), 87-92

Akabanda, F., Hlortsi, E.H., Kwarteng, J.O. (2017). Food safety knowledge, attitude and practices of institutional food handlers in Ghana. Biomedcental public health, 17(40),

Asmawi, U.M., Norehan, A.A., Salikin, K., Rosdi, N.A., Munur, N.A., Basri, N.B., Selamat, M.I., Nor, N.M. ( 2018). An assessment of knowledge, attitude Patient verbalized feeling of optimism, meaning in life and belief in God, self and others after 12hours of nursing intervention and practices in food safety among food handlers engaged in food courts. Current research in nutrition and food science, 6(2), 23.25.

Center for Disease Control and Prevention. (2017). Retrieved from https://www.cdc.gov/features/school-lunch-week/index.html

Dabik, S.D., Henry, O.A., Ojo, L., Afoakwa, E., Amshawu, A., Nwolley, A.K. (2018). Food hygiene awareness and environmental practices among food vendors in basic schools at Kintampo Township, Ghana. Food and public health, 8(1), 13-20

Emmanuel, A., Mangai, J.M., Kayong, E.A., Afoi, B.B., Goshit, J.D., Nanman, K., \& Innocent, O. (2015). Assessment of practice of food safety and hygiene among food vendors with Jos North Local government area of Plateau State, Nigeria. International journal of Medical and Health research, 1 (2), 83-86.

Ezenwoko, A.Z., Awosan, K.J., Oche, M.O., Makusidi, M.A., Abubakar, B.G., Raji, I.A. (2017). Knowledge and practices related to food hygiene among food handlers in Sokoto, Nigeria. International journal of tropical diseases \& health, 26(1), 1-16.

Faremi, A.F., Olatubi, I.M., Nnabuife, C.G., (2018). Food safety and hygiene practices among food vendors in a tertiary educational institution in South Western Nigeria. European journal of nutrition and food safety, 8(2), 59-70. Retrieved from http://creativecommons.org/licenses/by/4.0.

Food and Agricultural Organization (FAO) of the United Nations. (2018). Retrieved from http://www.fao.org/zhc/detail-events/en/c/462548 
Iwu, A.C., Uwakwo, K.A., Duru, C.B., Diwe, K.C., Chineke, H.N., Merenu, I.A., Oluoha, U.R., Madubueze, U.C., Ndukwu, E., Ohale, I.(2017). Knowledge, attitude and practices of food hygiene among food vendors in Owerri, Imo State, Nigeria. Occupational diseases and environmental medicine, 5, 11-25. Retrieved from http:www.scirp.org/journal/odem

Oghenekohwo, J.E. (2015). Pattern of food hygiene and environmental health practices among food vendors in Niger Delta University. European journal of food sciences and technology, 3(1), 24-40. Retrieved from http://www.eajournals.org

United States department of agriculture food safety and inspection services (2015). Retrieved from https://www.fsis.usda.gov/wps/portal/fsis/topics/food-safety-education/getanswers/food-safety-fact-sheets/safe-food-handling/keep-food-safe-food-safetybasics/ct_index

W.H.O. (2015). Food safety: what you should know. Retrieved from https://www.searo.who.int/entity/world_day/2015/whd-what-you-should-know/en/

Zenebe, M, Gebremedhin, S, Henry, C.J., Regassa, N. (2015). School feeding program has resulted in improved dietary diversity, nutritional status and class attendance of school children. Italian journal of pediatrics, 44(16), 1-10. Retrievd from https://www.ncnl.nlm.nib.gov/pmc/articles/PMC5782386 